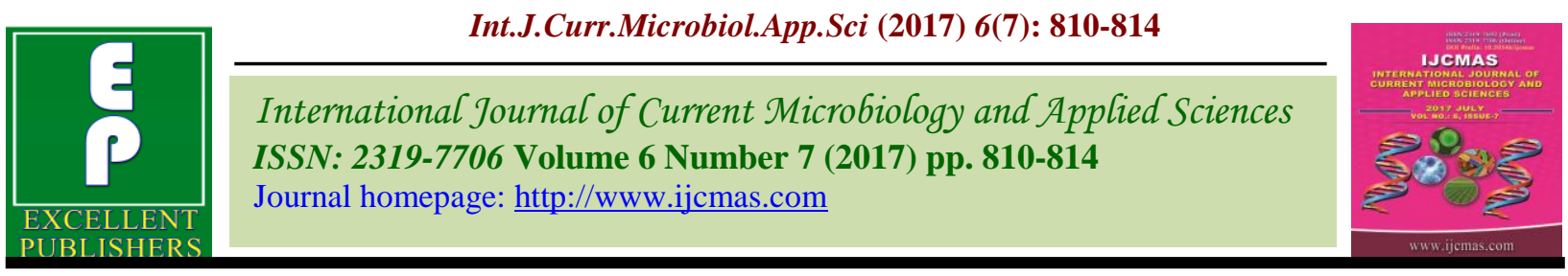

Original Research Article

https://doi.org/10.20546/ijcmas.2017.607.099

\title{
Varietal Evaluation of Gerbera (Gerbera jamesonii.) Grown in a Polyhouse
}

\author{
Manaswita Sil", Madhumita Mitra Sarkar, B. Raghupathi and Sourav Mondal
}

\author{
Department of Floriculture and Landscaping, Faculty of Horticulture, Bidhan Chandra Krishi \\ Viswavidyalaya, Mohanpur-741252, West Bengal, India \\ *Corresponding author
}

\section{A B S T R A C T}

\section{Keywords}

Yield and quality, Polyhouse, Vegetative parameters and Growth.

Article Info

Accepted: 14 June 2017 Available Online: 10 July 2017
A study was carried out from October, 2013 to February, 2015 at the Horticulture Research Station, Mondouri, of Bidhan Chandra Krishi Viswavidyalaya under subtropical plains, to evaluate the growth and flowering of 11 cultivars of Gerbera under polyhouse (Stanza, Inferno, Preintense, Brilliance, Balance, Paradisi, Goliath, Walhalla, Rosalin, Jaffna, Daneallean).Among the varieties studied, there were highly significant variations observed for growth, yield and quality parameters. The vegetative parameters studied were Individual Plant height, No. of leaves per clump, and Individual Leaf length; the flowering parameters recorded were Days to first flower bud emergence, Days to flower harvest, Self-life, Flower diameter, Floral disc diameter, and the yield and quality parameters measured were Individual Stalk length, Number of flowers per plant, and Individual Vase life. Among the cultivars studied, there were highly significant variations observed for growth, yield and quality parameters, as per indication of the results. The results were analyzed statistically using RBD (Randomized Block Design). Under the warm humid subtropical climate of West Bengal, the maximum no. of leaves (36.47) was produced by Balance, maximum growth in plant height $(55.52 \mathrm{~cm})$ was observed in Stanza while the maximum leaf length $(33.81 \mathrm{~cm})$ was recorded in Stanza. Among the cultivars, Inferno produced largest flowers with average diameter of $10.27 \mathrm{~cm}$. In terms of flower disc diameter, the highest measure was observed in Jaffna at $2.41 \mathrm{~cm}$. The shortest duration to reach harvest maturity (17.61) was observed in Daneallean. As per observation, Preintense showed the longest field life (23.84 days). Regarding the yield and quality parameters, the maximum no. of flowers (13.88) was produced by Stanza and Rosalin. The highest stalk length $(58.83 \mathrm{~cm})$ was found in Preintense. The cultivar with longest vase life (15.97 days) was Rosalin On the overall basis; the best performing cultivars have been Stanza, Rosalin, Preintense and Inferno respectively.

\section{Introduction}

Gerbera (Gerbera Jamesonii Hook.) is a dwarf stem-less herbaceous perennial herb growing in clump with solitary flower heads termed capitulum on a long slender stalk, well above the foliage. The leaves are petioled, lobed, coarse or sometimes tubular and two lipped and the flowers are daisy like in appearance available in wide range of colours.
Gerbera came into dictionary of Floriculture after it was discovered by pre-Linnaean botanist Gronovious, but it received its fortunate name in honour of German naturalist, Traugot Gerber, who travelled extensively in Russia. Gerbera belongs to family Asteraceae. This group at present comprises 45 species, native to tropical Asia 
and Africa. About seven species were recorded in India distributed in temperate Himalayas from Kashmir to Nepal at an altitude of 1300 to 3200 metres. It is considered as nature's one of the beautiful creations because of the excellent flowers with exquisite shape, size, and vibrant colours. It finds utility in garden beds, rock gardens, pot culture and also used extensively as cut flower.

\section{Materials and Methods}

The experiment was carried out at the Model Center on Floricultural Excellence, Horticulture Research Station, Mondouri Farm, Bidhan Chandra Krishi Viswavidyalaya, Mohanpur, Dist-Nadia, State-West Bengal. India, from October 2013 till February 2015. The experiment was laid out in Randomized Block Design, which was replicated thrice with 11treatments, namely, Stanza, Inferno, Preintense, Brilliance, Balance, Paradisi, Goliath, Walhalla, Rosalin, Jaffna, Daneallean, under polyhouse condition, with an aim to assess the performance of the Gerbera cultivars and the suitability of their cultivation under polyhouse condition applied in the subtropical plains of West Bengal.

\section{Results and Discussion}

The results of the present study as well as relevant discussion have been presented under following sub heads:

\section{Vegetative characters}

The parameters studied were Individual Plant Height, No. of Leaves per clump, and Individual Leaf Length. From the data presented in table 1, the maximum plant height $(55.52 \mathrm{~cm})$ was recorded in cultivar Stanza, followed by Balance $(51.17 \mathrm{~cm})$, whereas the shortest height among the cultivars was observed in cultivar Paradisi $(43.46 \mathrm{~cm})$, closely followed by cultivar Walhalla $(43.96 \mathrm{~cm})$. The maximum no. of leaves per clump $(36.47 \mathrm{~cm})$ was produced by cultivar Balance, followed by cultivar Goliath (35.84) while the minimum production of leaves (27.48) was recorded in cultivar Inferno, followed by cultivar Walhalla (28.91). The longest leaf $(33.81 \mathrm{~cm})$ was produced by cultivar Stanza, followed by cultivar Walhalla $(32.61 \mathrm{~cm})$. Minimum score in terms of leaf length $(22.48 \mathrm{~cm})$ was recorded in cultivar Inferno, followed by cultivar Brilliance $(26.67 \mathrm{~cm})$.

\section{Flower characters}

The parameters studied under this category were Days to First Flower Bud Emergence, Days to Harvest Maturity, Field Life, Flower Diameter, and Flower Disc Diameter. From the data presented in table 2 , it is evident that cultivar Brilliance is the earliest (97.76 days) of all cultivars to reach first flower bud emergence, closely followed by cultivar Goliath (98.34 days). However, the longest time taken to show first flower bud emergence was cultivar Jaffna (111.87 days), followed by cultivar Daneallean (110.63). The earliest cultivar (17.61 days) to reach harvest maturity was Daneallean, followed by Walhalla (18.61 days) whereas the cultivar that took longest time (21.97 days) to reach harvest maturity was cultivar Preintense followed by cultivar Inferno (21.74 days). Maximum field life (23.84 days) was recorded in cultivar Preintense followed by cultivar Stanza (22.86 days) while the minimum field life (18.67 days) was observed in cultivar Balance followed by cultivar Daneallean (18.83days). From table 1, it is gathered that cultivar Inferno produced the largest flower with an average diameter of $10.27 \mathrm{~cm}$, followed by cultivar Rosalin $(10.14 \mathrm{~cm})$. 
Table.1 Quality characters

\begin{tabular}{|c|c|c|c|c|c|c|c|}
\hline TREATMENT & $\begin{array}{c}\text { PLANT } \\
\text { HEIGHT }\end{array}$ & $\begin{array}{c}\text { NO. OF } \\
\text { LEAVES } \\
\text { PER CLUMP }\end{array}$ & $\begin{array}{c}\text { LEAF } \\
\text { LENGTH }\end{array}$ & $\begin{array}{c}\text { FLOWER } \\
\text { DIAMETER }\end{array}$ & $\begin{array}{c}\text { DISC } \\
\text { DIAMETER }\end{array}$ & $\begin{array}{c}\text { NO. OF } \\
\text { FLOWERS } \\
\text { PER PLANT }\end{array}$ & $\begin{array}{c}\text { STALK } \\
\text { LENGTH }\end{array}$ \\
\hline STANZA (T1) & 55.52 & 30.42 & 33.81 & 10.09 & 1.86 & 13.88 & 47.86 \\
\hline INFERNO (T2) & 45.92 & 27.48 & 22.48 & 10.27 & 2.22 & 9.96 & 44.59 \\
\hline PREINTENSE (T3) & 45.37 & 35.19 & 30.16 & 9.16 & 2.18 & 12.29 & 58.83 \\
\hline BRILLIANCE (T4) & 44.07 & 34.54 & 26.67 & 8.97 & 2.12 & 10.77 & 49.36 \\
\hline BALANCE (T5) & 51.17 & 36.47 & 29.78 & 10.11 & 1.99 & 12.00 & 45.76 \\
\hline PARADISI (T6) & 43.46 & 30.84 & 29.90 & 10.08 & 1.64 & 11.99 & 39.93 \\
\hline GOLIATH (T7) & 44.97 & 35.84 & 29.97 & 9.19 & 1.52 & 12.26 & 57.62 \\
\hline WALHALLA (T8) & 43.96 & 28.91 & 32.61 & 9.60 & 2.36 & 13.44 & 54.00 \\
\hline ROSALIN (T9) & 45.94 & 33.54 & 32.31 & 10.14 & 1.43 & 13.88 & 52.01 \\
\hline JAFFNA (T10) & 48.51 & 32.81 & 29.66 & 9.86 & 2.41 & 11.37 & 46.70 \\
\hline DANEALLEAN (T11) & 44.53 & 30.19 & 29.60 & 9.92 & 2.33 & 10.40 & 51.81 \\
\hline $\operatorname{Sem}(+-)$ & 1.40 & 0.92 & 0.19 & 0.11 & 0.04 & 0.65 & 0.06 \\
\hline CD 5\% & 4.13 & 2.72 & 0.55 & 0.31 & 0.11 & 1.91 & 0.19 \\
\hline
\end{tabular}

Table.2 Yield characters

\begin{tabular}{|c|c|c|c|c|}
\hline TREATMENT & $\begin{array}{c}\text { DAYS TO FIRST FLOWER } \\
\text { BUD EMERGENCE }\end{array}$ & $\begin{array}{c}\text { DAYS TO HARVEST } \\
\text { MATURITY }\end{array}$ & $\begin{array}{l}\text { FIELD } \\
\text { LIFE }\end{array}$ & VASE LIFE \\
\hline STANZA (T1) & 102.27 & 20.48 & 22.86 & 12.61 \\
\hline INFERNO (T2) & 101.67 & 21.74 & 19.61 & 8.91 \\
\hline PREINTENSE (T3) & 105.86 & 21.97 & 23.84 & 15.47 \\
\hline BRILLIANCE (T4) & 97.76 & 19.54 & 20.54 & 9.92 \\
\hline BALANCE (T5) & 104.62 & 21.53 & 18.67 & 6.16 \\
\hline PARADISI (T6) & 109.58 & 20.83 & 18.93 & 6.61 \\
\hline GOLIATH (T7) & 98.34 & 18.97 & 21.33 & 7.99 \\
\hline WALHALLA (T8) & 99.94 & 18.61 & 19.84 & 9.96 \\
\hline ROSALIN (T9) & 100.72 & 19.80 & 22.66 & 15.97 \\
\hline JAFFNA (T10) & 111.87 & 19.86 & 20.96 & 6.72 \\
\hline DANEALLEAN (T11) & 110.63 & 17.61 & 18.83 & 7.16 \\
\hline $\operatorname{Sem}(+-)$ & 0.04 & 0.04 & 0.03 & 0.04 \\
\hline CD $5 \%$ & 0.13 & 0.13 & 0.08 & 0.11 \\
\hline
\end{tabular}


On the other hand, the smallest flower $(8.97 \mathrm{~cm})$ was produced by cultivar Brilliance, followed by cultivar Preintense $(9.16 \mathrm{~cm})$. Maximum flower disc diameter $(2.41 \mathrm{~cm})$ was observed in cultivar Jaffna, followed by cultivar Walhalla $(2.36 \mathrm{~cm})$, whereas the smallest flower disc (1.43) was found to be produced by cultivar Rosalin, followed by cultivar Goliath $(1.52 \mathrm{~cm})$.

\section{Yield and quality characters}

The parameters observed were Number of Flowers per plant, Individual Stalk Length, and Individual Vase Life. According to the data studied in table 1 , the cultivar producing the maximum no. of flowers (13.88) were cultivars Stanza and Rosalin, followed by Walhalla (13.44). The cultivar that produced the minimum no. of flowers (9.96) was cultivar Inferno, followed by cultivar Daneallean (10.40).

The cultivar recorded to produce the highest stalk length $(58.83 \mathrm{~cm})$ was cultivar Preintense, followed by cultivar Goliath $(57.62 \mathrm{~cm})$. However, the shortest stalk $(39.93 \mathrm{~cm})$ was produced by cultivar Paradisi, followed by Inferno $(44.59 \mathrm{~cm})$. Maximum vase life (15.97 days) was observed in cultivar Rosalin, followed by cultivar Preintense (15.47 days), whereas the shortest vase life was recorded in cultivar Balance (6.16 days), followed by cultivar Paradisi (6.61 days).

It can be concluded from the experiment conducted, that there were certain anomalies and differences in respect to vegetative growth, flower yield and quality among the genotypes, which could be attributed to the fluctuations in temperature according to season and also to the distinct genetic constitution of each of the cultivar. Gerberas for the market are usually preferred with higher stalk length, bright and even coloration of florets, uniformly opened florets, larger sized flowers and with a long and robust vase life. Considering all the parameters studied and cultivars evaluated the cultivars that emerged most suitable for commercial cultivation in warm subtropical plains of West Bengal, were Stanza (T1), Rosalin (T9) and Preintense (T3) respectively.

\section{References}

Acharya, Baral, Gautam, Pun. (2010). Influence of Seasons and Varieties on Vase Life of Gerbera (Gerbera jamesonii Hook.) Nepal Journal of Science and Technology Vol.11 41-46

Anop Kumari, K.S Patel, D.D Nayee (2010) Evaluation of different cultivars of Gerbera (Gerbera jamesonii Bolus ex hooker F.) for growth, yield and quality grown under fan and pad cooled greenhouse conditions The Asian Journal of Horticulture, Vol.5, No.2, 309-310

Ahlawat, T. R., Barad, A. V. and Giriraj, Jat. (2012). Evaluation of gerbera cultivar under naturally ventilated polyhouse. Indian Journal of Horticulture.69 (4): 606-608

A. K. Senapati, Priyanka Prajapati and Alka Singh (2013). Genetic variability and heritability studies in Gerbera jamesonii Bolus. African Journal of Agricultural Research Vol. 8(41), pp. 5090-5092

BHAT, V.C., 1995. Evaluation of gerbera (Gerbera jamesonii Hybrida) genotypes. M.Sc. (Agri.) Thesis, University of Agricultural Sciences, Dharwad.

Bose, T.K., Yadav, L.P., Pal, P., Pathasarathy, V.P. and Das, P. (2003) Commercial flowers (2nd Ed.). Naya Udyog, Calcutta, India.

Chauhan, N. (2005). Performance of gerbera genotypes under protected cultivation. Dept. Hort. College of Agri, Dharwad 
Univs. Agri. Sci. Dharwad.

Chobe, R. R., Pachankar, P. B. and Warade, S. D. (2010). Performance of different cultivars of gerbera under polyhouse condition. The Asian Journal of Horticulture. 2: 333-335

Choudhary, M.L. and Prasad, K.V. (2000). Protected cultivation of ornamental crops-an insight. Indian Hort. 45 (1): 4953.

Rajiv Kumar and D.S. Yadav Evaluation of Gerbera (Gerbera jamesonii Bolus ex. Hooker f.) genotypes for vegetative and flower quality under polyhouse. (2013) Hortflora Research Spectrum, Vol.2 (3), 244-246

Sarmah, Kolukunde, Mandal. (2014) Evaluation of gerbera varieties for growth and flowering under polyhouse in the plains of West Bengal International Journal of Scientific Research Vol.3, Issue.12, ISSN No.2277-8179

Magar, Warade, Nalge and Nimbalkar (2010) Performance of Gerbera (Gerbera jamesonii) under naturally ventilated polyhouse condition. International Journal of Plant Sciences (July, 2010) Vol.5, Issue.2, 609-612

Mahmood, Ahmed and Khan (2013) Comparative Evaluation of growth, yield and quality characteristics of various Gerbera (Gerbera jamesonii L) cultivars under protected conditions. Journal of Ornamental Plants, Vol.3, No.4, 235-241.

\section{How to cite this article:}

Manaswita Sil, Madhumita Mitra Sarkar, B. Raghupathi and Sourav Mondal. 2017. Varietal Evaluation of Gerbera (Gerbera Jamesonii.) Grown in a Polyhouse. Int.J.Curr.Microbiol.App.Sci. 6(7): 810-814. doi: https://doi.org/10.20546/ijcmas.2017.607.099 